\title{
Trichodinid ectoparasites (Ciliophora: Peritrichia) of freshwater fishes of the family Anabantidae from the Okavango River and Delta (Botswana)
}

\author{
Linda Basson and Jo G. Van As
}

Department of Zoology and Entomology, University of the Free State, P.O. Box 339, Bloemfontein, 9300, South Africa

Key words: Trichodina, Tripartiella, new species, freshwater fishes, climbing perches, Botswana

\begin{abstract}
During parasitological surveys in the Okavango Delta and Panhandle in Botswana, two species of climbing perches belonging to the family Anabantidae were investigated for ectoparasites. The fishes were the blackspot climbing perch, Microctenopoma intermedium (Pellegrin) and the manyspined climbing perch, Ctenopoma multispine Peters. Five trichodinid species were found from the skin, fins and gills of these anabantids. One is a known species, i.e., Trichodina microspina Van As et Basson, 1992, for which a comparative description is provided. Four other species are described as new species using silver impregnation, i.e., Trichodina labyrinthipiscis sp. n., Trichodina anabantidarum sp. n., Tripartiella microctenopomae sp. n., and Tripartiella ctenopomae sp. n.
\end{abstract}

The Okavango Delta, in the midst of the Kalahari Desert, is the largest wetland and one of the last remaining pristine wilderness areas in Africa. The Okavango River rises in the highlands of Angola and enters Botswana from the north-west. Here the river, confined by two parallel geological faults, meanders southeastwards through a papyrus swamp of about $15 \mathrm{~km}$ wide, known as the Panhandle. Upon reaching the Gomare geological fault, the river fans out to form the largest inland delta in the world (Fig. 1). The Okavango Delta is a dynamic ecosystem, driven by an annual flood, which takes about six months to flow the distance of approximately $250 \mathrm{~km}$ as the crow flies from Mohembo in the north to Maun in the south.

The fish population of the Okavango System in Botswana comprises 68 species of which 23 are endemic to the Okavango and upper Zambesi River System (Skelton et al. 1985, Skelton 1993). So far the Okavango Delta has not been exposed to any introductions or translocations of any species of fish. Various studies of the fish populations in Botswana have been carried out, but until recently, when our group became involved, no studies existed on the fish parasites of the Okavango Delta. Van As and Basson (1992) described several trichodinid species from the adjacent Zambesi River System, a system sharing a common origin in the Angolan highlands.

Four papers dealing with other parasites have so far been published from the work done in the Okavango Delta; these are those by Van As and Van As (1999), Smit et al. (2000), Moravec and Van As (2001), and Reed et al. (2002). The present paper deals with trichodinids from the fish family Anabantidae and is the first of a series on the trichodinids from fishes of the Okavango Delta.

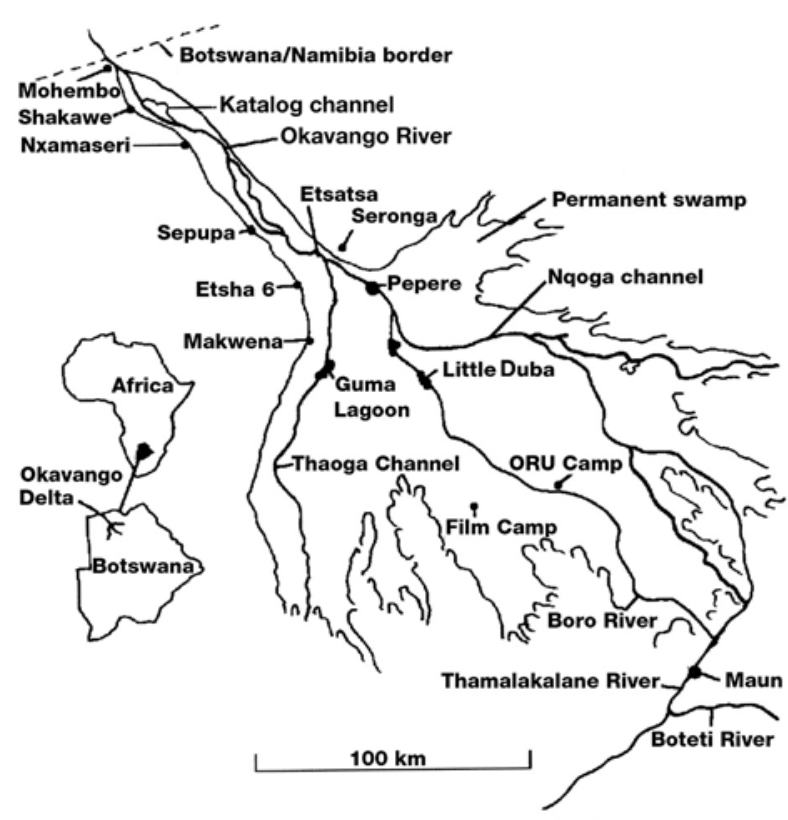

Fig. 1. Map of the sampling localities in the Okavango Panhandle and Delta, Botswana.

The family Anabantidae belongs to one of the "labyrinth" fish families and its representatives are found in Africa and southern and south-eastern Asia, including the Philippines and Malay Archipelago. Wellknown representatives of this family are the gouramis, Siamese fighting fishes and paradise fishes. These fishes are characterised by the accessory air-breathing organs within chambers above the gills. These structures are composed of lamellae, covered over with a highly vascular layer of skin, many times folded and 
convoluted. Atmospheric air, taken in through the mouth, is forced into the labyrinth where gas exchange takes place. The labyrinth is not present in young fish and only develops some weeks after hatching. This structure is necessary as many of these fishes live in tropical swamps and streams with low oxygen levels. The family includes three genera in Africa of which two species are found in the Okavango Delta. These two species were found to harbour five trichodinid species, three of which belong to the genus Trichodina Ehrenberg, 1838 and two to the genus Tripartiella Lom, 1959. Of these one is known, i.e. Trichodina microspina Van As et Basson, 1992, for which a comparative description is provided, whilst the other four are described as new species.

\section{MATERIALS AND METHODS}

Four fish parasite surveys were carried out over a four-year period from 1997 to 2000 in various localities within the Okavango Panhandle and Delta in Botswana. The first survey was in the early summer of October 1997, followed by three trips during the winters of 1998, 1999 and 2000, each fieldtrip extending over a period of two and a half months.

Forty-two specimens of the blackspot climbing perch, Microctenopoma intermedium (Pellegrin) and 16 specimens of the manyspined climbing perch, Ctenopoma multispine Peters were collected from different habitats, mostly floodplains and backwaters in the Panhandle and Delta using hand nets, cast nets and wire gauze scoops.

Wet smears of the skin and gills were prepared and examined in the field laboratory for the presence of trichodinids with the use of a compound microscope. No trichodinids were found on the accessory air-breathing organs. Back in the laboratory in Bloemfontein, air-dried smears were impregnated with silver nitrate in order to study details of the adhesive disc. Differential interference contrast (DIC) was used in all photomicrographs. Some smears were also stained with Mayer's haematoxylin for studying the nuclear apparatus. All measurements are presented in micrometres $(\mu \mathrm{m})$ and follow the uniform specific characteristic system proposed by Lom (1958). A detailed description of the denticles is pre-sented in accordance with the method proposed by Van As and Basson (1989). Minimum and maximum values are given, followed in parentheses by the arithmetic mean and standard deviation, but standard deviation is not supplied for popula-tions where less than ten specimens were measured. In the case of the denticles and radial pins, the mode is provided instead of the arithmetic mean. Body diameter is measured as the adhesive disc plus border membrane. In the case of the two Tripartiella species, the adhesive discs are oblong, not round. In order to account for this in the description, measurements on both the long and short axis were determined for body-, adhesive disc- and denticle ring diameters, as well as the coinciding measurements for the blade- and ray lengths and central part width. These are provided in Table 4, where the complete measurements determined on the long axis are provided first, followed by those of the short axis.

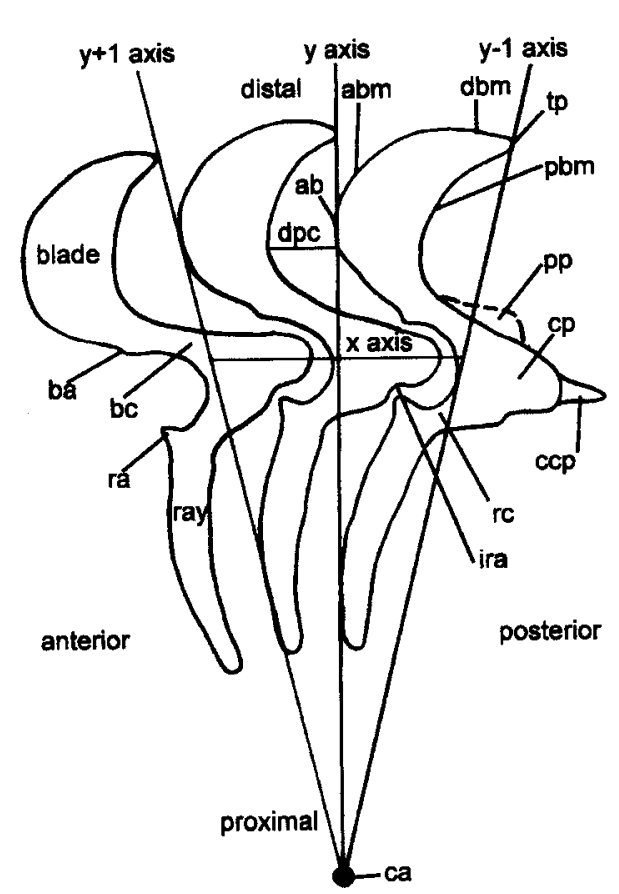

Fig. 2. Schematic drawing of denticles of Trichodina magna Van As et Basson, 1989 to illustrate the sequence and method of the description of denticle elements, according to the method of Van As and Basson (1989). Abbreviations: ab blade apex, abm - anterior blade margin (surface), ba - blade apophysis, bc - blade connection, ca - centre of adhesive disc, ccp - central conical part, $\mathrm{cp}$ - central part, dbm - distal blade margin (surface), dpc - deepest point of curve relative to apex, ira - indentation in lower central part, pbm - posterior blade margin (surface), $\mathrm{pp}$ - posterior projection, ra - ray apophysis, $\mathrm{rc}$ - ray connection, tp - tangent point.

Type material is deposited in the collection of the National Museum, Bloemfontein (South Africa), while reference material is in the collection of the authors.

\section{Morphology of trichodinid denticles}

Since proposing a method for detailed description of the trichodinid denticles by Van As and Basson (1989), many authors describing new species of the genus Trichodina have followed this method like Nilsen (1995), Su and White (1995), Asmat and Haldar (1998) and Xu et al. (1999a, b). We find the method particularly useful, not only for the description of species, but also for comparing the denticle shape of species in existing publications. In the present paper this method will be applied to species of the genus Tripartiella for the first time. Since there are considerable differences in the denticle morphology of these two genera, this requires a brief revisit of the method proposed by us. In our original proposal of a method for denticle description, we used the terminology "blade surface" (for both distal and anterior) as well as "posterior blade surface". We would like to suggest that the term margin be used instead of surface, i.e., distal and anterior blade margins as well as posterior blade margin. 

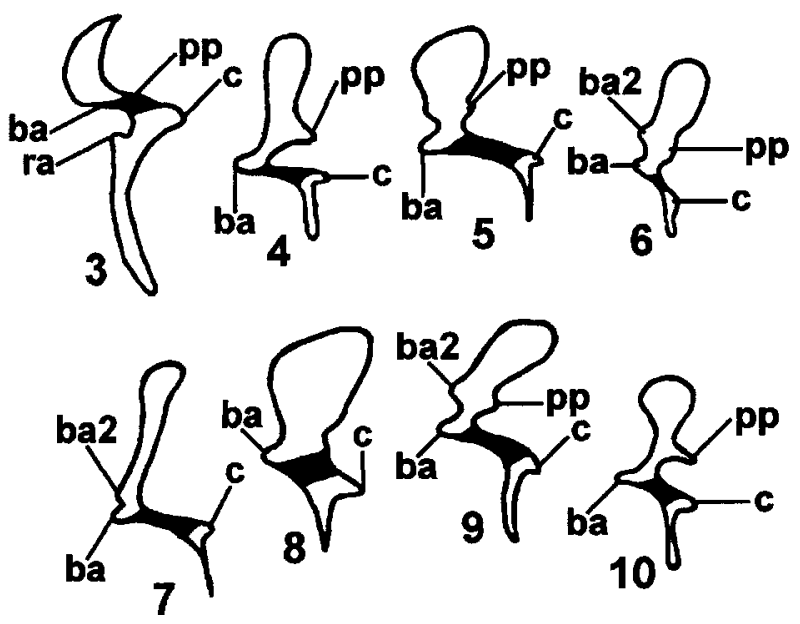

Figs. 3-10. Schematic drawings of trichodinid denticles. Fig. 3. Trichodina magna Van As et Basson, 1989. Fig. 4. Tripartiella orthodens Basson et Van As, 1987. Fig. 5. Tripartiella nana Basson et Van As, 1987. Fig. 6. Tripartiella lechridens Basson et Van As, 1987. Fig. 7. Tripartiella cichlidarum Basson, Van As et Paperna, 1983. Fig. 8. Tripartiella leptospina Basson et Van As, 1987. Fig. 9. Tripartiella macrosoma Basson et Van As, 1987. Fig. 10. Tripartiella clavodonta Basson et Van As, 1987. Abbreviations: ba - blade apophysis, ba2 - second blade apophysis, $\mathrm{c}-$ central part, $\mathrm{pp}$ - posterior projection, $\mathrm{ra}$ - ray apophysis.

In Figs. 2 and 3 the denticles of a typical representative of the genus Trichodina are illustrated. The blade apophysis on the anterior side of the blade and the posterior projections are not well developed or prominent in these denticles. In representatives of the genus Tripartiella, as illustrated in Figs. 410 , the blade apophyses are well developed and prominent and facilitate articulation between two consecutive denticles. In some species a second blade apophysis is present (Figs. 5, 7, $9)$. The posterior projections of some of these species (Figs. 4$6,9,10)$ are also well developed and presumably also instrumental in articulation between consecutive denticles. In all the Tripartiella species illustrated in Figs. 4-10 the blade connections (indicated in black) are extended structures, with the central parts small, the rays projecting directly from the central part and the ray connections and ray apophyses absent.

\section{RESULTS AND DISCUSSION}

Trichodina microspina Van As et Basson, 1992

Figs. 11, 12, 17; Table 1

Biometrical data of two populations from the Okavango are summarised in Table 1, together with comparative measurements of $T$. microspina originally described from Namibia by Van As and Basson (1992).
Description: Small-sized trichodinid with high cylindrical body. Adoral ciliary spiral $405-415^{\circ}$. Blade broad, filling almost entire space between y axes. Distal part of blade rounded, almost parallel to border membrane, sloping slightly down towards $y+1$. Tangent point mostly sharp, but rounded in some specimens. Tangent point slightly below distal margin. Anterior margin round, with clear apex, extending to y axes, sometimes beyond. Blade apophysis present, in some specimens prominent. Posterior margin with shallow curve, deepest point situated low. Blade connection not distinguishable. Central part delicate, sloping slightly downwards in most specimens, but in some straight. Central part fitting loosely onto blade apophysis of preceding denticle. Ray short, ray connection not distinguishable. Rays delicate and short, tapering to sharp points. Ray apophysis not detectable. Ratio of denticle above to denticle below $\mathrm{x}$ axis more than two (2.5).

$\mathrm{H}$ o s t: Microctenopoma intermedium (Pellegrin).

$\mathrm{O}$ the r h o s t: Ctenopoma multispine Peters.

$\mathrm{S}$ i t e : Mostly skin and fins, occasionally also gills.

L o c a 1 i t i e s: Mohembo Backwaters, Guma Floodplains, Guma Lagoon, Little Duba Backwaters, Etsatsa Backwaters, Seronga Backwaters (M. intermedium); Mohembo Backwaters, Pepere Backwaters (C. multispine).

R e f e r e n c e m a t e r i a 1 : Slide 1997/10/26-61 (Microctenopoma intermedium from Mohembo Backwaters, Okavango Delta, Botswana) in the collection of the authors.

Remarks: This trichodinid with its unique denticle shape is clearly distinguishable from all other species. It was previously recorded from an adjacent river system (Zambesi River) in Namibia from Ctenopoma multispine. Van As and Basson (1992) described this species from a single small population found in only one of the localities in the Zambesi System, i.e., Lake Lisikili.

An interesting phenomenon of this species that has not previously been noted is that the centre of the adhesive disc has a structure similar to a central circle found in some species such as Trichodina compacta Van As et Basson, 1989 and T. acuta Lom, 1961. In the latter cases these circles impregnated in the same way as the denticle, i.e. are non-argentophilic. In the case of the central circle in $T$. microspina, the impregnation is not as distinct. In this case the centre shows an affinity for silver nitrate, thus being argentophilic. This structure is, however, definitely a slightly elevated surface, clearly visible in DIC micrographs (Figs. 11, 12). The presence of this structure sometimes distorts the rays and in some cases even conceals them (Fig. 11). Without being aware of this, Van As and Basson (1992) included a figure where this structure is also clearly visible (fig. 7A, Van As and Basson 1992). 

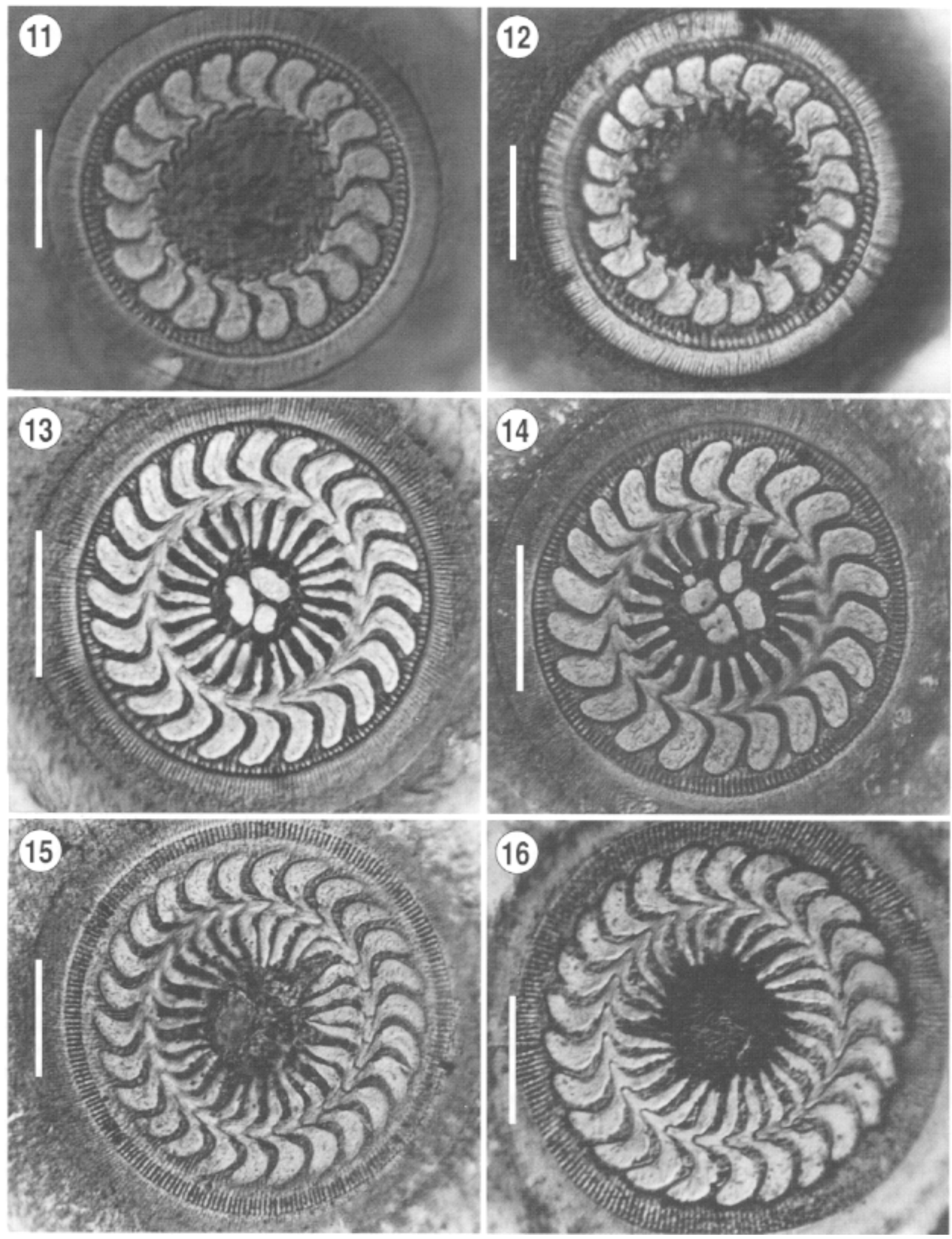

Figs. 11-16. Photomicrographs of silver-impregnated adhesive discs of Trichodina Ehrenberg, 1838 species. Figs. 11, 12. Trichodina microspina Van As et Basson, 1992 from the skin and fins of Microctenopoma intermedium. Figs. 13, 14. Trichodina labyrinthipiscis sp. n. from the gills of M. intermedium. Figs. 15, 16. Trichodina anabantidarum sp. n. from the gills of M. intermedium. Scale bars $=15 \mu \mathrm{m}$. 
Table 1. Biometrical data (in $\mu \mathrm{m}$ ) of different populations of Trichodina microspina Van As et Basson, 1992.

\begin{tabular}{|c|c|c|c|}
\hline Host & $\begin{array}{l}\text { Ctenopoma } \\
\text { multispine }\end{array}$ & $\begin{array}{l}\text { Microctenopoma } \\
\text { intermedium }\end{array}$ & Ctenopoma multispine \\
\hline Locality & Namibia & Okavango & Okavango \\
\hline Position in host & skin and fins & $\begin{array}{l}\text { mostly skin and fins, } \\
\text { occasionally gills }\end{array}$ & $\begin{array}{l}\text { mostly skin and fins, } \\
\text { occasionally gills }\end{array}$ \\
\hline Reference & $\begin{array}{l}\text { Van As and Basson } \\
\text { (1992) }\end{array}$ & present study & present study \\
\hline Body diameter & $\begin{array}{c}25.0-35.0 \\
(29.8 \pm 2.4)\end{array}$ & $\begin{array}{c}26.0-38.0 \\
(31.8 \pm 3.3)\end{array}$ & $\begin{array}{c}30.0-38.0 \\
(33.7 \pm 2.0)\end{array}$ \\
\hline Adhesive disc diameter & $\begin{array}{c}19.5-28.5 \\
(24.6 \pm 2.3)\end{array}$ & $\begin{array}{c}20.5-33.0 \\
(26.7 \pm 3.5)\end{array}$ & $\begin{array}{c}25.0-33.0 \\
(28.3 \pm 2.1)\end{array}$ \\
\hline Border membrane width & $\begin{array}{c}2.0-3.5 \\
(2.6 \pm 0.4)\end{array}$ & $\begin{array}{c}2.0-3.0 \\
(2.3 \pm 04)\end{array}$ & $\begin{array}{c}2.0-3.0 \\
(2.5 \pm 0.3)\end{array}$ \\
\hline Denticle ring diameter & $\begin{array}{c}10.0-16.5 \\
(13.7 \pm 1.7)\end{array}$ & $\begin{array}{c}12.0-20.0 \\
(15.6 \pm 2.4)\end{array}$ & $\begin{array}{c}14.5-21.5 \\
(16.9 \pm 1.8)\end{array}$ \\
\hline Denticle number & $18-22(20)$ & $18-22(20)$ & $19-23(22)$ \\
\hline Radial pins/denticle & $6-8(7)$ & $6-8(7)$ & $6-7(6)$ \\
\hline Denticle length & $\begin{array}{c}3.0-4.5 \\
(3.7 \pm 0.3)\end{array}$ & $\begin{array}{c}3.0-5.0 \\
(3.8 \pm 0.7)\end{array}$ & $\begin{array}{c}3.5-4.5 \\
(3.9 \pm 1.5)\end{array}$ \\
\hline Blade length & $\begin{array}{c}2.0-3.5 \\
(2.7 \pm 0.4)\end{array}$ & $\begin{array}{c}2.0-4.0 \\
(3.3 \pm 0.6)\end{array}$ & $\begin{array}{c}2.5-4.0 \\
(3.4 \pm 0.4)\end{array}$ \\
\hline Central part width & $\begin{array}{c}1.0-1.5 \\
(1.2 \pm 0.2)\end{array}$ & $\begin{array}{c}0.5-1.5 \\
(1.0 \pm 0.2)\end{array}$ & $\begin{array}{c}0.5-1.0 \\
(1.0 \pm 0.1)\end{array}$ \\
\hline Ray length & $\begin{array}{c}1.0-2.0 \\
(1.3 \pm 0.3)\end{array}$ & $\begin{array}{c}0.5-2.0 \\
(1.2 \pm 0.3)\end{array}$ & $\begin{array}{c}0.5-1.5 \\
(1.1 \pm 0.3)\end{array}$ \\
\hline Denticle span & $\begin{array}{c}4.5-6.5 \\
(5.2 \pm 0.5)\end{array}$ & $\begin{array}{c}4.5-6.5 \\
(5.4 \pm 0.6)\end{array}$ & $\begin{array}{c}4.5-6.5 \\
(5.5 \pm 0.6)\end{array}$ \\
\hline Macronucleus - shape & - & U-C shaped & - \\
\hline $\begin{array}{l}\text { Macronucleus - external } \\
\text { diameter }\end{array}$ & - & $\begin{array}{c}19.0-34.3 \\
(27.6 \pm 3.9)\end{array}$ & - \\
\hline Macronucleus - thickness & - & $\begin{array}{c}3.1-11.9 \\
(6.0 \pm 2.6)\end{array}$ & - \\
\hline Macronucleus - x value & - & $\begin{array}{c}1.7-23.2 \\
(13.3 \pm 5.8)\end{array}$ & - \\
\hline Micronucleus - shape & - & round to oval & - \\
\hline Micronucleus - length & - & $\begin{array}{c}2.1-5.7 \\
(3.3 \pm 0.9)\end{array}$ & - \\
\hline Micronucleus - width & - & $\begin{array}{c}0.8-2.7 \\
(1.6 \pm 0.6)\end{array}$ & - \\
\hline Micronucleus - y position & - & mostly $+y$, some in $-y$ & - \\
\hline Micronucleus - y value & - & $\begin{array}{c}0-8.8 \\
(4.2 \pm 2.4) \\
\end{array}$ & - \\
\hline Adoral spiral & mostly $405^{\circ}$ & $405-415^{\circ}$ & $440^{\circ}$ \\
\hline $\mathrm{n} 1$ & 19 & 25 & 17 \\
\hline $\mathrm{n} 2$ & - & 25 & - \\
\hline
\end{tabular}

Minimum and maximum values are given, followed in parentheses by the arithmetic mean and standard deviation. In the case of the number of denticles and radial pins, the mode is given instead of the arithmetic mean. Body diameter is measured from silver-impregnated specimens as the adhesive disc plus border membrane. n1 - number of silver-impregnated specimens measured, n2 - number of haematoxylin-stained specimens measured for nuclear apparatus.

\section{Trichodina labyrinthipiscis sp. n.}

Figs. 13, 14, 18; Table 2

Biometrical data of two populations from the Okavango are summarised in Table 2.

Description: Medium-sized trichodinid. Blade broad, sickle-shaped. Adoral ciliary spiral $380-435^{\circ}$. Distal blade margin rounded, tangent point round, lower than distal blade margin. Anterior blade margin slopes sharply downwards, extending slightly beyond $\mathrm{y}+1$ axis. Apex prominent, bluntly rounded. Blade apophysis present and in some specimens even prominent. Posterior blade margin with deep curve, deepest point on same level as apex, or even higher. Blade connection prominent, clearly distinguishable from blade. Central part tapering sharply towards rounded point, extends halfway to $\mathrm{y}-1$ axis, fitting tightly into preceding 

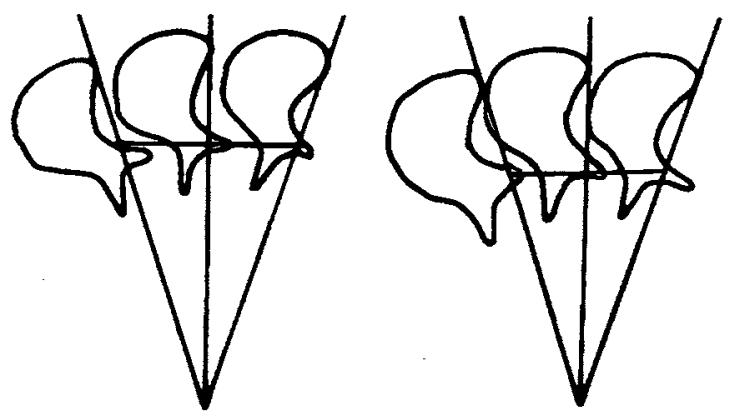

Fig. 17. Diagrammatic drawings of the denticles of two specimens of Trichodina microspina Van As et Basson, 1992 from the skin and fins of Microctenopoma intermedium.
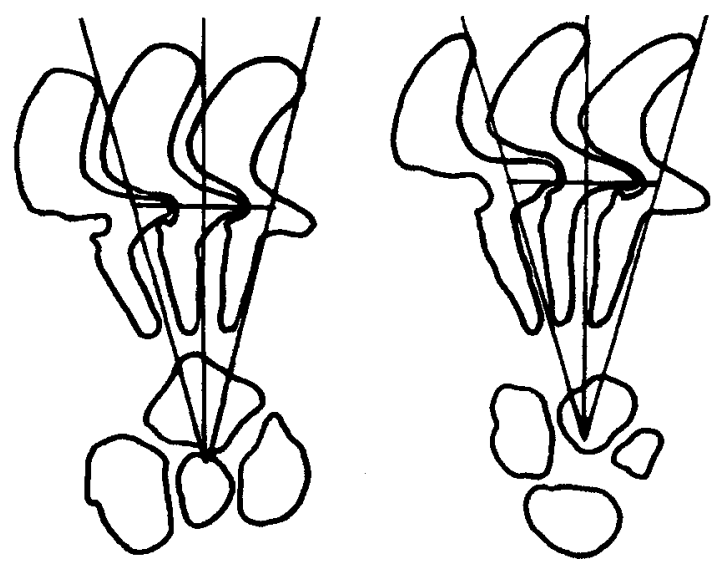

Fig. 18. Diagrammatic drawings of the denticles of two specimens of Trichodina labyrinthipiscis sp. $\mathrm{n}$. from the gills of Microctenopoma intermedium.

denticle. Indentation in lower central part distinct, corresponding to ray apophysis. Ray connection broad. Ray apophysis prominent, directed in distal direction. Rays robust, broad at bases, tapering slowly towards round tips, extending parallel to $y$ axes. Ratio of denticle above to denticle below $\mathrm{x}$ axis slightly more than one (1.2-1.3).

Centre of disc with 1-6 unequal argentophilic celllike structures of uneven shapes and sizes.

T y p e host: Microctenopoma intermedium (Pellegrin).

$\mathrm{O}$ th e r h o st: Ctenopoma multispine Peters.

$\mathrm{S}$ i t e : Mostly gills, rarely skin and fins.

T y p e 1 o c a 1 i t y : Guma Lagoon $\left(18^{\circ} 57^{\prime} 44.9^{\prime \prime} \mathrm{S}\right.$, $\left.22^{\circ} 22^{\prime} 26.7^{\prime \prime} \mathrm{e}\right)$.

O the r 1 o c a 1 it i e s: Mohembo Backwaters, Guma Floodplains, Little Duba Backwaters, Seronga Backwaters (M. intermedium); Pepere Backwaters (C. multispine).

T y p e m a te ri a l: Holotype, slide 1999/06/28-13 (NMBP 232), and paratype, slide 1999/06/28-15 (NMBP 233) in the collection of the National Museum, Bloemfontein,
Table 2. Biometrical data (in $\mu \mathrm{m}$ ) of Trichodina labyrinthipiscis sp. n. from the Okavango Delta (Botswana).

\begin{tabular}{|c|c|c|}
\hline Host & $\begin{array}{l}\text { Microctenopoma } \\
\text { intermedium }\end{array}$ & $\begin{array}{l}\text { Ctenopoma } \\
\text { multispine }\end{array}$ \\
\hline Locality & Okavango & Okavango \\
\hline Position in host & gills, rarely skin & gills \\
\hline Reference & present study & present study \\
\hline Body diameter & $\begin{array}{c}41.0-54.0 \\
(45.9 \pm 3.3)\end{array}$ & $\begin{array}{c}41.0-52.0 \\
(44.3)\end{array}$ \\
\hline $\begin{array}{l}\text { Adhesive disc } \\
\text { diameter }\end{array}$ & $\begin{array}{c}31.0-46.0 \\
(37.4 \pm 3.8)\end{array}$ & $\begin{array}{c}33.0-48.0 \\
(36.8)\end{array}$ \\
\hline $\begin{array}{l}\text { Border membrane } \\
\text { width }\end{array}$ & $\begin{array}{c}3.0-5.5 \\
(4.0 \pm 0.5)\end{array}$ & $\begin{array}{c}4.0-4.5 \\
(4.2)\end{array}$ \\
\hline $\begin{array}{l}\text { Denticle ring } \\
\text { diameter }\end{array}$ & $\begin{array}{c}19.5-29.0 \\
(22.7 \pm 2.2)\end{array}$ & $\begin{array}{c}18.5-28.5 \\
(21.6)\end{array}$ \\
\hline $\begin{array}{c}\text { Denticle ring } \\
\text { structures }\end{array}$ & $\begin{array}{c}1-6 \\
(3.6 \pm 1.1)\end{array}$ & $\begin{array}{c}(21.9) \\
2-9 \\
(5.7)\end{array}$ \\
\hline Denticle number & $20-25(22)$ & $22-26(23)$ \\
\hline Radial pins/denticle & $8-9(9)$ & $7-9(9)$ \\
\hline Denticle length & $\begin{array}{c}5.0-7.0 \\
(5.9 \pm 0.6)\end{array}$ & $\begin{array}{c}4.0-6.0 \\
(5.3)\end{array}$ \\
\hline Blade length & $\begin{array}{c}4.0-7.7 \\
(5.3 \pm 0.7)\end{array}$ & $\begin{array}{c}2.0-9.0 \\
(5.7)\end{array}$ \\
\hline Central part width & $\begin{array}{c}1.5-2.5 \\
(2.0 \pm 0.3)\end{array}$ & $\begin{array}{c}4.0-6.0 \\
(5.6)\end{array}$ \\
\hline Ray length & $\begin{array}{c}4.0-6.0 \\
(4.7 \pm 0.6)\end{array}$ & $\begin{array}{c}1.0-2.5 \\
(1.8)\end{array}$ \\
\hline Denticle span & $\begin{array}{c}11.0-14.0 \\
(12.4 \pm 0.9)\end{array}$ & $\begin{array}{c}5.5-6.5 \\
(5.9)\end{array}$ \\
\hline $\begin{array}{l}\text { Macronucleus - } \\
\text { shape }\end{array}$ & U-C shaped & - \\
\hline $\begin{array}{l}\text { Macronucleus - } \\
\text { external diameter }\end{array}$ & $\begin{array}{c}33.2-48.0 \\
(38.3 \pm 2.9)\end{array}$ & - \\
\hline $\begin{array}{l}\text { Macronucleus - } \\
\text { thickness }\end{array}$ & $\begin{array}{c}2.3-6.9 \\
(5.4 \pm 1.0)\end{array}$ & - \\
\hline $\begin{array}{l}\text { Macronucleus - } \\
\quad \mathrm{x} \text { value }\end{array}$ & $\begin{array}{c}7.4-27.9 \\
(18.8 \pm 6.0)\end{array}$ & - \\
\hline $\begin{array}{l}\text { Micronucleus - } \\
\text { shape }\end{array}$ & round & - \\
\hline $\begin{array}{l}\text { Micronucleus - } \\
\text { length }\end{array}$ & $3.7-4.6(4.0)$ & - \\
\hline $\begin{array}{l}\text { Micronucleus - } \\
\text { width }\end{array}$ & $1.4-3.4(2.5)$ & - \\
\hline $\begin{array}{l}\text { Micronucleus - } \\
\text { y position }\end{array}$ & $\begin{array}{l}\text { mostly not visible, } \\
\text { when visible } \\
\text { in }+y \text { or }-y \text { position }\end{array}$ & - \\
\hline $\begin{array}{l}\text { Micronucleus - } \\
\text { y value }\end{array}$ & $0-19.6(5.7)$ & - \\
\hline Adoral spiral & $380-435^{\circ}$ & - \\
\hline n1 & 30 & 6 \\
\hline $\mathrm{n} 2$ & 25 (ma), 4 (mi) & - \\
\hline
\end{tabular}

ma - macronucleus, mi - micronucleus. For other explanation see Table 1.

South Africa and slide 1999/06/28-16 in the collection of the Institute of Parasitology, Academy of Sciences of the Czech Republic, Branišovská 31, 37005 České Budějovice, Czech Republic (H-PM-051).

E t y m o 1 o g y : Named after general name for fish group (labyrinth fishes). 
Remarks: The cell-like structures in the centre of the adhesive disc, although differing in size and number in different specimens, are a consistent feature of this species. The only other known freshwater trichodinid with similar features is Trichodina reticulata Hirschmann et Partsch, 1955, associated with European cyprinids and reported by various authors such as Lom (1960), Stein (1968), Lom et al. (1976) and Van Than and Margaritov (1986). This species consistently has a larger number of cells arranged in a reticulated manner compared to the present species. The blade, central part and ray of $T$. reticulata differ from those of $T$. labyrinthipiscis. Trichodina reticulata is also slightly larger and has more denticles than T. labyrinthipiscis. This European species has recently been found on introduced goldfish from a pet shop in Bloemfontein, South Africa (Basson and Van As 1993).

\section{Trichodina anabantidarum sp. n.}

$$
\text { Figs. 15, 16, 19; Table } 3
$$

Biometrical data of two populations from the Okavango are summarised in Table 3.

Description: Medium-sized trichodinid. Adoral ciliary spiral $410^{\circ}$. Blade broad, open sickle-shaped. Distal blade margin rounded. Tangent point lower than distal blade margin. Anterior blade margin sloping gently towards $\mathrm{y}+1$ axis. Margin extending to and in some specimens slightly past $\mathrm{y}+1$ axis. Apex slightly flattened. Blade apophysis prominent, posterior blade margin with deep curve, deepest point at same level or below apex in some specimens. Blade connection prominent. Posterior projection not visible. Central part tapering sharply towards thin rounded point, fitting tightly into preceding denticle. Indentation in lower central part present, opposing apophysis of ray. Ray connection slightly thinner than base of ray. Ray apophysis prominent, directed anteriorly, opposing indentation in lower central part. Rays broad with tapered points. Rays straight, but directed slightly anteriorly, not extending past $\mathrm{y}$ axes. Ratio of denticle above to below $\mathrm{x}$ axis slightly more than one (1.1-1.3).

T y p e h o s t: Microctenopoma intermedium (Pellegrin).

$\mathrm{O}$ th e r h o s t : Ctenopoma multispine Peters.

$\mathrm{S}$ i t e : Mostly gills, occasionally skin and fins.

T y p e 1 o c a 1 i t y : Mohembo Backwaters (1903'26.3”S, $22^{\circ} 23^{\prime}$ '15.9'"E).

O t h e r 1 o c a 1 i t i e s : Guma Floodplains, Little Duba Backwaters, Etsatsa Backwaters (M. intermedium); Mohembo Backwaters, Pepere Backwaters (C. multispine).

T y p e m a t e r i a 1 : Holotype, slide 1997/10/26-63 (NMBP 234), and paratype, slide 1997/10/26-78 (NMBP 241) in the collection of the National Museum, Bloemfontein, South Africa and slide 1997/10/27-31 in the collection of the Institute of Parasitology, Academy of Sciences of the
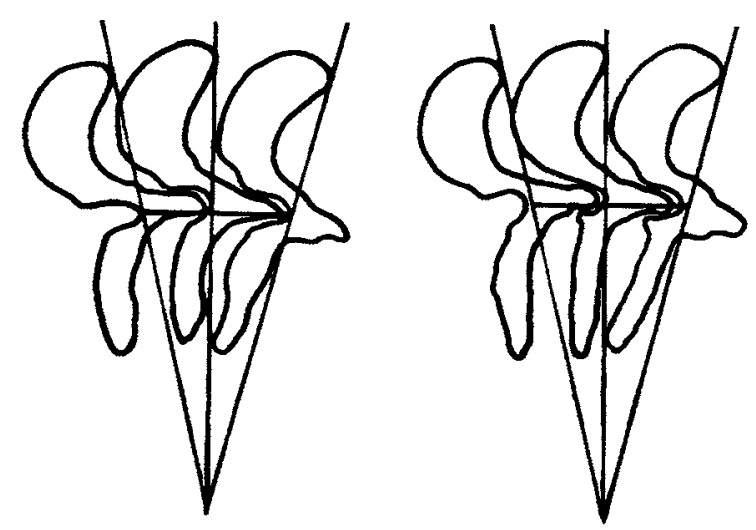

Fig. 19. Diagrammatic drawings of the denticles of two specimens of Trichodina anabantidarum sp. $\mathrm{n}$. from the gills of Microctenopoma intermedium.

Czech Republic, Branišovská 31, 37005 České Budějovice, Czech Republic (H-PM-052).

E t y m o lo g y : Named after fish family.

Remarks: The general denticle morphology of $T$. anabantidarum shows some resemblance to T. magna Van As et Basson, 1989 and T. maritinkae Basson et Van As, 1991, both previously recorded from different localities in southern Africa, including the Zambesi River System (Van As and Basson 1992). Trichodina magna, a much larger species, has very consistent thin, sickle-shaped blades. The rays are always directed in an anterior direction and are distinctly curved. This species has been recorded from a large variety of southern African fishes, where it normally occurs in small numbers, mostly on the skin. Trichodina maritinkae is restricted to the gills of clariid fishes and is a highly specific species that has never been recorded from any other hosts than clariids. It is of the same size order as T. anabantidarum, but differs from the latter in having broad, closed, sickle-shaped blades and thin, sharply pointed rays.

\section{Tripartiella microctenopomae sp. $\mathrm{n}$.}

Figs. 20-22, 26; Table 4

Biometrical data from the Okavango are summarised in Table 4.

Description: Adoral ciliary spiral $135-160^{\circ}$. Blade broad, not curved, distal blade margin rounded, following curve of border membrane. Tangent point rounded, lower than distal blade margin. Anterior blade margin forms straight axis, extending for more than half its length past $y+1$ axis. Blade apophysis prominent, extending to $y+2$ axis, fitting tightly into indentation of next blade. Posterior blade margin not curved, following roughly straight axis, slanted in anterior direction from $y$ axis to $y+1$ axis. Posterior projection present but not distinct. Pronounced indentation on lower part of blade corresponding to anterior projection 
Table 3. Biometrical data (in $\mu \mathrm{m}$ ) of Trichodina anabantidarum sp. n., Trichodina magna Van As et Basson, 1989 (from Van As and Basson 1989) and Trichodina maritinkae Basson et Van As, 1991 (from Van As and Basson 1992).

\begin{tabular}{|c|c|c|c|c|}
\hline Trichodinid species & $\begin{array}{c}\text { Trichodina } \\
\text { anabantidarum }\end{array}$ & $\begin{array}{c}\text { Trichodina } \\
\text { anabantidarum }\end{array}$ & Trichodina magna & $\begin{array}{l}\text { Trichodina } \\
\text { maritinkae }\end{array}$ \\
\hline Host & $\begin{array}{c}\text { Microctenopoma } \\
\text { intermedium }\end{array}$ & $\begin{array}{l}\text { Ctenopoma } \\
\text { multispine }\end{array}$ & $\begin{array}{l}\text { Tilapia rendalli } \\
\text { swierstrae }\end{array}$ & Clarias stappersii \\
\hline Locality & Okavango & Okavango & South Africa & $\begin{array}{l}\text { Zambesi River } \\
\text { (Namibia) }\end{array}$ \\
\hline Position in host & $\begin{array}{c}\text { mostly gills, } \\
\text { occasionally skin }\end{array}$ & gills & skin and fins & gills \\
\hline Reference & present study & present study & $\begin{array}{c}\text { Van As and Basson } \\
(1989)\end{array}$ & $\begin{array}{c}\text { Van As and Basson } \\
\text { (1992) }\end{array}$ \\
\hline Body diameter & $\begin{array}{c}49.0-61.0 \\
(57.3 \pm 3.3)\end{array}$ & $\begin{array}{l}57.0-59.0 \\
(58)\end{array}$ & $\begin{array}{c}71.2-111.8 \\
(99.1 \pm 9.5)\end{array}$ & $\begin{array}{c}43.5-59.5 \\
(52.0 \pm 7.2)\end{array}$ \\
\hline $\begin{array}{l}\text { Adhesive disc } \\
\text { diameter }\end{array}$ & $\begin{array}{c}39.0-54.0 \\
(49.2 \pm 4.0)\end{array}$ & 50 & $\begin{array}{c}59.7-94.8 \\
(81.8 \pm 8.2)\end{array}$ & $\begin{array}{c}35.0-50.2 \\
(43.4 \pm 6.6)\end{array}$ \\
\hline $\begin{array}{l}\text { Border membrane } \\
\text { width }\end{array}$ & $\begin{array}{c}3.0-5.0 \\
(4.0 \pm 0.5)\end{array}$ & $\begin{array}{c}4.0-4.5 \\
(4.2)\end{array}$ & $\begin{array}{c}6.2-13.9 \\
(8.9 \pm 1.4)\end{array}$ & $\begin{array}{c}3.0-5.5 \\
(4.3 \pm 0.6)\end{array}$ \\
\hline $\begin{array}{l}\text { Denticle ring } \\
\text { diameter }\end{array}$ & $\begin{array}{c}23.0-32.0 \\
(28.1 \pm 2.2)\end{array}$ & $\begin{array}{l}28.5-30.0 \\
(29.5)\end{array}$ & $\begin{array}{c}35.6-57.5 \\
(50.0 \pm 4.8)\end{array}$ & $\begin{array}{c}20.5-29.5 \\
(25.4 \pm 2.5)\end{array}$ \\
\hline Denticle number & $21-28(24)$ & $24-26$ & $24-27(25)$ & $20-25(22)$ \\
\hline $\begin{array}{l}\text { Radial pins / } \\
\text { denticle }\end{array}$ & $9-11(9 \& 10)$ & $8-9$ & $10-13(11)$ & 8-10 (9) \\
\hline Denticle length & $\begin{array}{c}6.0-8.0 \\
(7.1 \pm 0.5)\end{array}$ & $\begin{array}{l}7.0-8.0 \\
(7.5)\end{array}$ & $\begin{array}{c}7.4-13.6 \\
(10.9 \pm 1.4)\end{array}$ & $\begin{array}{c}5.0-7.5 \\
(6.2 \pm 0.6)\end{array}$ \\
\hline Blade length & $\begin{array}{c}5.0-7.0 \\
(5.9 \pm 0.5)\end{array}$ & $\begin{array}{c}6.0-7.0 \\
(6.5)\end{array}$ & $\begin{array}{c}6.0-10.9 \\
(8.6 \pm 0.9)\end{array}$ & $\begin{array}{c}3.0-5.0 \\
(4.1 \pm 0.4)\end{array}$ \\
\hline Central part width & $\begin{array}{c}1.5-2.0 \\
(1.9 \pm 0.2)\end{array}$ & $\begin{array}{c}1.5-2.0 \\
(1.8)\end{array}$ & $\begin{array}{c}3.7-7.4 \\
(5.6 \pm 0.9)\end{array}$ & $\begin{array}{c}1.0-2.5 \\
(2.0 \pm 0.3)\end{array}$ \\
\hline Ray length & $\begin{array}{c}6.0-7.5 \\
(6.7 \pm 0.6)\end{array}$ & $\begin{array}{l}6.0-8.0 \\
(7)\end{array}$ & $\begin{array}{c}7.7-16.0 \\
(13.0 \pm 1.7)\end{array}$ & $\begin{array}{c}4.0-7.5 \\
(6.1 \pm 0.8)\end{array}$ \\
\hline Denticle span & $\begin{array}{c}13.5-17.0 \\
(14.8 \pm 0.9)\end{array}$ & $\begin{array}{c}14.0-16.0 \\
(15.3)\end{array}$ & & $\begin{array}{c}9.0-14.0 \\
(12.2 \pm 1.1)\end{array}$ \\
\hline $\begin{array}{l}\text { Macronucleus - } \\
\text { shape }\end{array}$ & U-shaped & - & U-shaped & closed C-shaped \\
\hline $\begin{array}{l}\text { Macronucleus - } \\
\text { external } \\
\text { diameter }\end{array}$ & $\begin{array}{l}37.1-43.4 \\
\quad(40.7)\end{array}$ & - & $\begin{array}{c}47.2-82.1 \\
(62.2 \pm 9.2)\end{array}$ & $\begin{array}{c}36.0-50.5 \\
(42.4 \pm 4.5)\end{array}$ \\
\hline $\begin{array}{l}\text { Macronucleus - } \\
\text { thickness }\end{array}$ & $\begin{array}{c}5.0-6.3 \\
(5.6)\end{array}$ & - & $\begin{array}{c}5.8-9.8 \\
(8.1 \pm 1.1)\end{array}$ & $\begin{array}{c}4.5-11.0 \\
(7.1 \pm 1.4)\end{array}$ \\
\hline $\begin{array}{l}\text { Macronucleus - } \\
\quad \mathrm{x} \text { value }\end{array}$ & $\begin{array}{l}10.6-15.8 \\
(13.4)\end{array}$ & - & $\begin{array}{c}7.0-38.6 \\
(14.9 \pm 9.0)\end{array}$ & $\begin{array}{c}5.5-24.5 \\
(11.7 \pm 5.3)\end{array}$ \\
\hline $\begin{array}{l}\text { Micronucleus - } \\
\text { shape }\end{array}$ & Round & - & not detected & oval \\
\hline $\begin{array}{l}\text { Micronucleus - } \\
\text { length }\end{array}$ & $\begin{array}{c}2.7-5.1 \\
(3.6)\end{array}$ & - & - & $\begin{array}{c}2.5-9.0 \\
(4.4 \pm 1.3)\end{array}$ \\
\hline $\begin{array}{l}\text { Micronucleus - } \\
\text { width }\end{array}$ & $\begin{array}{c}1.7-4.9 \\
(3.0)\end{array}$ & - & - & $\begin{array}{c}1.0-3.0 \\
(2.1 \pm 0.5)\end{array}$ \\
\hline $\begin{array}{l}\text { Micronucleus - } \\
\text { y position }\end{array}$ & $+\mathrm{y}$ & - & - & $\begin{array}{l}\text { mostly }+\mathrm{y} \\
\text { rarely }-\mathrm{y}^{1}\end{array}$ \\
\hline $\begin{array}{l}\text { Micronucleus - } \\
\text { y value }\end{array}$ & $\begin{array}{c}1.1-13.3 \\
(9.8)\end{array}$ & - & - & $\begin{array}{c}2.5-27.5 \\
(14.4 \pm 10.2)\end{array}$ \\
\hline Adoral spiral & $410^{\circ}$ & - & $400^{\circ}$ & $400-420^{\circ}$ \\
\hline n1 & 16 & 3 & 22 & 25 \\
\hline $\mathrm{n} 2$ & 4 & - & 12 & 23 \\
\hline
\end{tabular}

For explanation see Table 1. 
Table 4. Biometrical data (in $\mu \mathrm{m}$ ) of Tripartiella microctenopomae sp. n., Tripartiella ctenopomae sp. n., Tripartiella cichlidarum Basson, Van As et Paperna, 1983 (from Basson et al. 1983) and Tripartiella macrosoma Basson et Van As, 1987 (from Basson and Van As 1987).

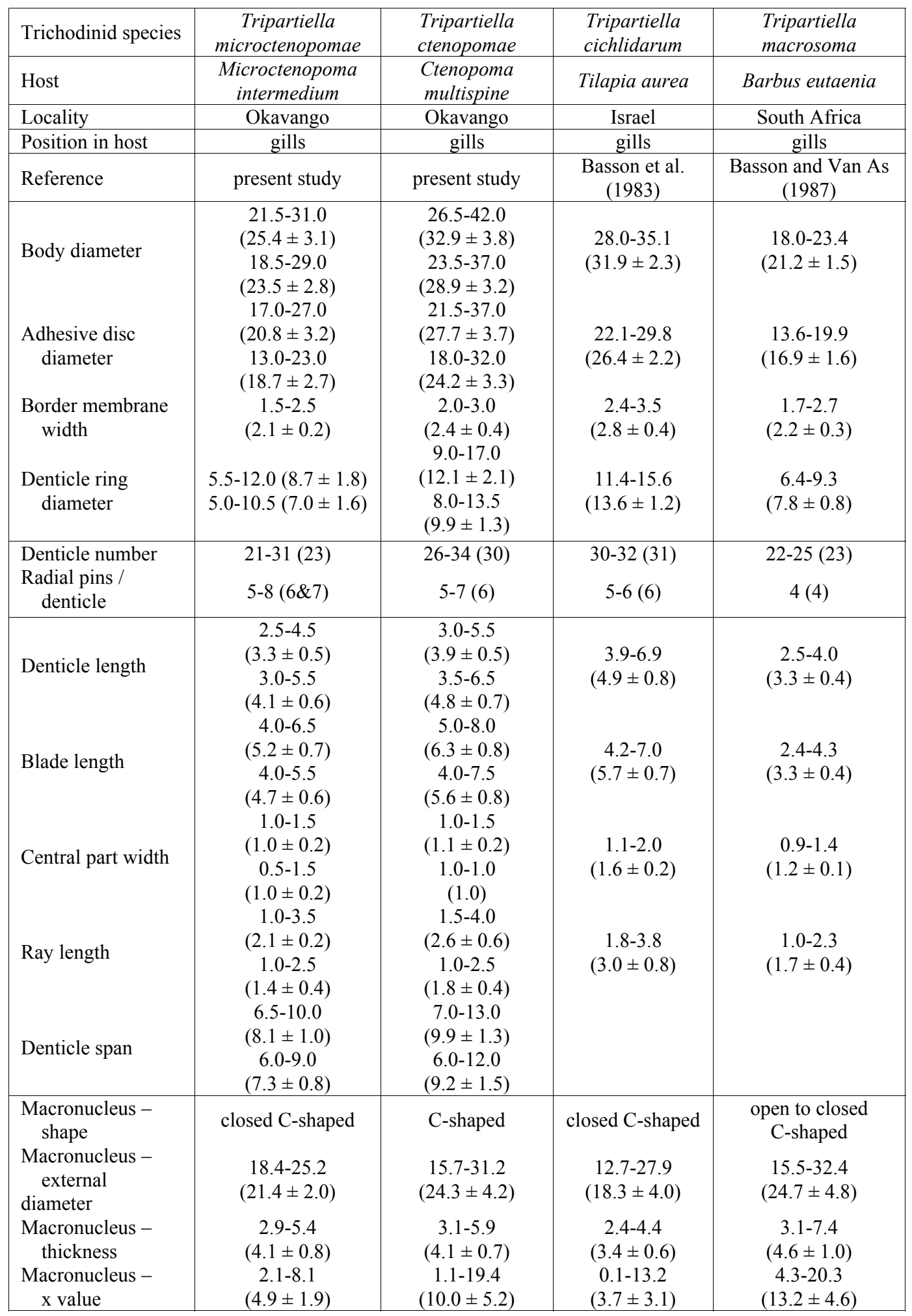

(continued) 
Table 4. (continued from p. 177)

\begin{tabular}{|c|c|c|c|c|}
\hline Trichodinid species & $\begin{array}{c}\text { Tripartiella } \\
\text { microctenopomae }\end{array}$ & $\begin{array}{l}\text { Tripartiella } \\
\text { ctenopomae }\end{array}$ & $\begin{array}{l}\text { Tripartiella } \\
\text { cichlidarum }\end{array}$ & $\begin{array}{l}\text { Tripartiella } \\
\text { macrosoma }\end{array}$ \\
\hline Host & $\begin{array}{c}\text { Microctenopoma } \\
\text { intermedium }\end{array}$ & $\begin{array}{l}\text { Ctenopoma } \\
\text { multispine }\end{array}$ & Tilapia aurea & Barbus eutaenia \\
\hline Locality & Okavango & Okavango & Israel & South Africa \\
\hline Position in host & gills & gills & gills & gills \\
\hline Reference & present study & present study & $\begin{array}{l}\text { Basson et al. } \\
\text { (1983) }\end{array}$ & $\begin{array}{c}\text { Basson and Van As } \\
\text { (1987) }\end{array}$ \\
\hline $\begin{array}{l}\text { Micronucleus - } \\
\text { shape }\end{array}$ & round to oval & oval & not detected & not detected \\
\hline $\begin{array}{l}\text { Micronucleus - } \\
\text { length }\end{array}$ & $\begin{array}{l}2.3-3.0 \\
(2.7)\end{array}$ & $\begin{array}{c}2.0-5.6 \\
(3.4 \pm 0.8)\end{array}$ & - & - \\
\hline $\begin{array}{l}\text { Micronucleus - } \\
\text { width }\end{array}$ & $\begin{array}{c}1.5-2.1 \\
(1.8)\end{array}$ & $\begin{array}{c}1.0-1.7 \\
(1.4 \pm 0.2)\end{array}$ & - & - \\
\hline $\begin{array}{l}\text { Micronucleus - } \\
\text { y position }\end{array}$ & $\begin{array}{c}\text { Mostly not } \\
\text { detected, if visible } \\
+\mathrm{y} \text { or }-\mathrm{y}\end{array}$ & $+\mathrm{y}$ & - & - \\
\hline $\begin{array}{l}\text { Micronucleus - } \\
\text { y value }\end{array}$ & $\begin{array}{c}1.7-7.8 \\
(4.9 \pm 3.4) \\
\end{array}$ & $\begin{array}{c}1.0-16.0 \\
(9.4 \pm 4.2)\end{array}$ & - & - \\
\hline Adoral spiral & $135-160^{\circ}$ & $185-290^{\circ}$ & $180^{\circ}$ & $170-230^{\circ}$ \\
\hline $\mathrm{n} 1$ & 22 & 25 & 12 & 25 \\
\hline $\mathrm{n} 2$ & $10(\mathrm{ma}), 4(\mathrm{mi})$ & 25 & 18 & 18 \\
\hline
\end{tabular}

For body-, adhesive disc and denticle ring diameters, measurements are provided first for long, then short axis, with corresponding measurements for blade- and ray lengths as well as central part width. ma - macronucleus, mi - micronucleus. For other explanation see Table 1.
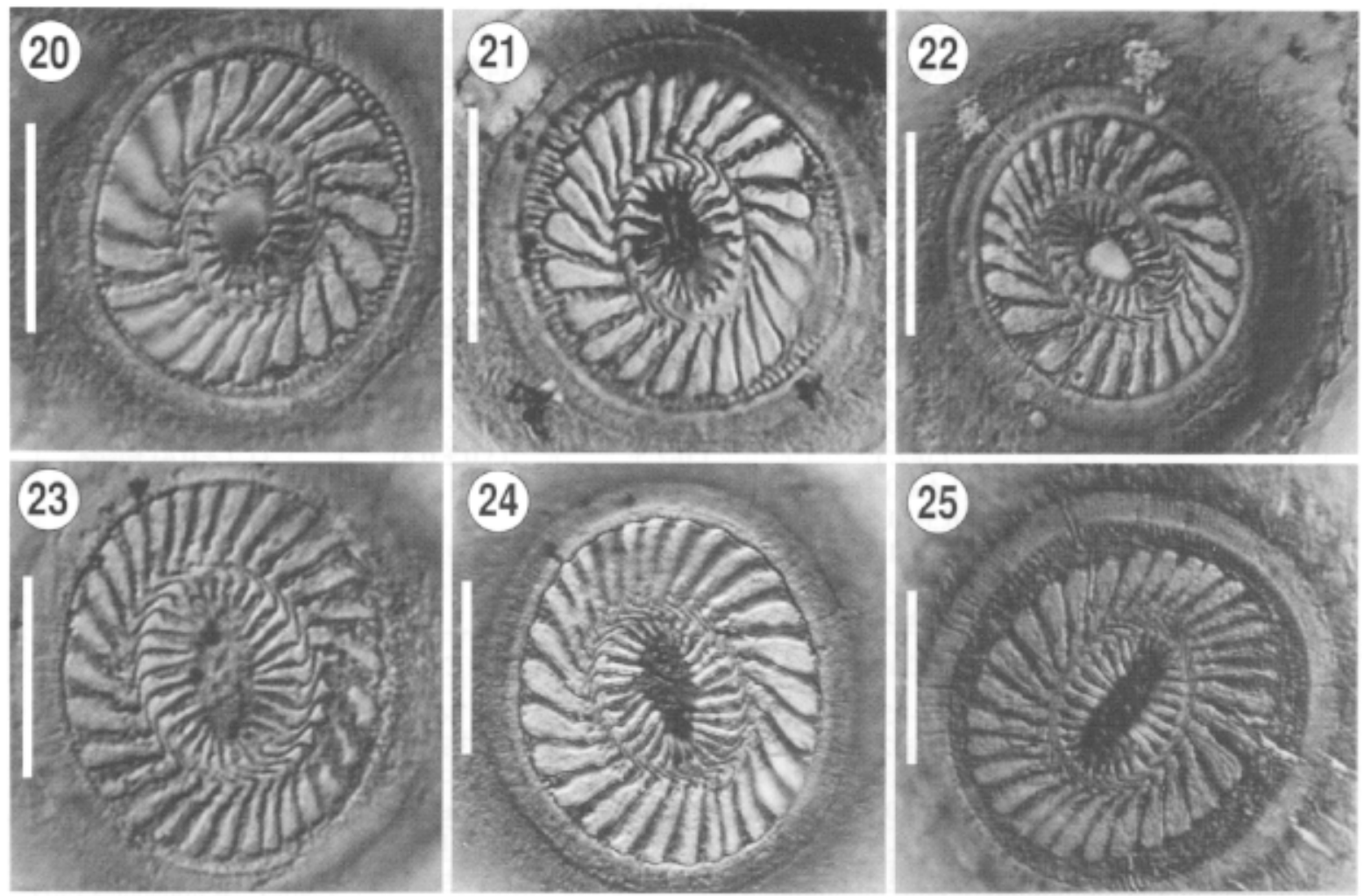

Figs. 20-25. Photomicrographs of silver-impregnated adhesive discs of Tripartiella Lom, 1959 species. Figs. 20-22. Tripartiella microctenopomae sp. $\mathrm{n}$. from the gills of Microctenopoma intermedium. Figs. 23-25. Tripartiella ctenopomae $\mathrm{sp}$. $\mathrm{n}$. from the gills of Ctenopoma multispine. Scale bars $=10 \mu \mathrm{m}$. 


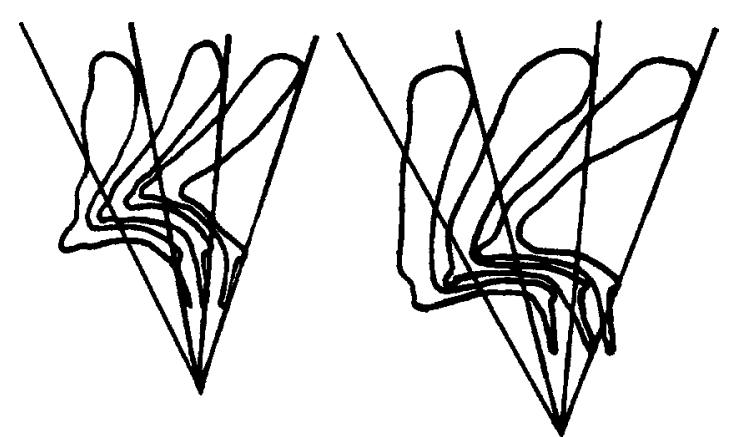

Fig. 26. Diagrammatic drawings of the denticles of two specimens of Tripartiella microctenopomae sp. $\mathrm{n}$. from the gills of Microctenopoma intermedium.

of previous blade. Blade connection thin and long, of equal thickness, extending from $\mathrm{y}+1$ to $\mathrm{y}-1$ axis, slanting in distal direction. Central part small, bulbous. Rays of unequal length, straight, extend directly from central parts. Angle of posterior blade margin to blade connection almost $90^{\circ}$, with section of blade from tangent point to blade apophysis extending to almost two y segments. Ratio of denticle above to below $\mathrm{x}$ axis more than four (4.4-5.1).

Remarks: See remarks for Tripartiella ctenopomae below.

T y p e hos t: Microctenopoma intermedium (Pellegrin).

$S$ i t e : Gills only.

T y p e 1 o c a 1 i t y : Makwena Floodplains $\left(19^{\circ} 03\right.$ '26.3"S, $22^{\circ} 23$ '15.9”'E).

O t h e r 1 o c a 1 i t i e s : Mohembo Backwaters, Guma Lagoon, Little Duba Backwaters, Seronga Backwaters.

T y p e m a te r i a 1 : Holotype, slide 1998/07/07-01 (NMBP 242), and paratype, slide 1998/07/07-02 (NMBP 243) in the collection of the National Museum, Bloemfontein, South Africa and slide 1998/07/07-04 in the collection of the Institute of Parasitology, Academy of Sciences of the Czech Republic, Branišovská 31, 37005 České Budějovice, Czech Republic (H-PM-053).

E t y m o log y : Named after generic name of type host.

\section{Tripartiella ctenopomae sp. $\mathrm{n}$.}

Figs. 23-25, 27; Table 4

Biometrical data from the Okavango are summarised in Table 4.

Description: Adoral ciliary spiral $185-290^{\circ}$. Blades generally broad with rounded bulbous distal parts. In other specimens blade narrower with anterior and posterior margins parallel. Distal margin rounded. Tangent point lower than distal margin. Anterior blade margin sloping downwards, extending past $y+1$ axis for almost half its length. Second blade apophysis pronounced, corresponding to indentation in anterior mar-
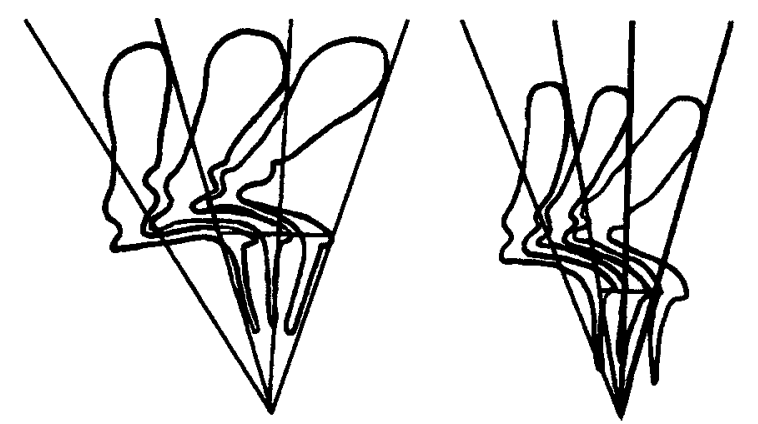

Fig. 27. Diagrammatic drawings of the denticles of two specimens of Tripartiella ctenopomae sp. $\mathrm{n}$. from the gills of Ctenopoma multispine.

gin of next blade. Blade apophysis distinct, extending tightly into indentation of next denticle. Posterior blade margin extending from y axis sloping down towards $\mathrm{y}+1$ axis. Posterior projection distinct, preceded by deep hollow, corresponding to second blade apophysis situated higher towards distal part of blade. Blade connection thin and long, of equal thickness throughout, extending over more than $1 \frac{1}{2}$ y segments, slanting almost parallel to border membrane. Central part small and delicate with ray extending directly from central part, almost in straight line with y axis. Angle of posterior blade margin to blade connection sharp, less than $90^{\circ}$, with section of blade from tangent point to blade apophysis extending over two y segments. Rays of unequal lengths in single specimen. Ratio of denticle above to below $\mathrm{x}$ axis more than two (2.2-2.5).

$\mathrm{T}$ y p e h o s t : Ctenopoma multispine Peters.

S i t e : Gills only.

T y p e 1 o c a 1 i t y : Makwena Floodplains $\left(19^{\circ} 03^{\prime} 26.3\right.$ "S, 2223'15.9'E).

O t h e r 1 o c a 1 i t i e s : Guma Floodplains, Pepere Backwaters.

T y p e m a t e r i a 1 : Holotype, slide 1998/07/07-57 (NMBP 244), and paratype, slide 1998/07/07-58 (NMBP 245) in the collection of the National Museum, Bloemfontein, South Africa and slide 1998/07/07-61 in the collection of the Institute of Parasitology, Academy of Sciences of the Czech Republic, Branišovská 31, 37005 České Budějovice, Czech Republic (H-PM-054).

E t y m o l o g y : Named after generic name of type host.

Remarks: Tripartiella microctenopomae and $T$. ctenopomae are obviously closely related in sharing common characteristics. Upon closer examination, however, the distinction becomes quite apparent. Tripartiella ctenopomae is distinctly larger, mean body diameter $32.9 \mu \mathrm{m}$, which is well above the largest specimen recorded for $T$. microctenopomae. This also applies to the diameter of the denticle ring, which in $T$. ctenopomae was $12.1 \mu \mathrm{m}$ (mean), whilst the largest 
specimen of $T$. microctenopomae was $12.0 \mu \mathrm{m}$ with a mean of $8.7 \mu \mathrm{m}$. Tripartiella ctenopomae has a mode of 30 denticles, with $T$. microctenopomae having 23. There are also considerable differences in the adoral spiral: in the former species it varied from $185^{\circ}$ to $290^{\circ}$, well above that of $135-160^{\circ}$ recorded for the latter species.

The denticles differ in the following way, apart from all denticle dimensions being larger in T. ctenopomae, the following can also be noted; the angle formed by the blade and blade connection in T. microctenopomae is about $90^{\circ}$, but less than $90^{\circ}$ in $T$. ctenopomae. The blade connection slants downwards in $T$. microctenopomae, whilst roughly following the curve of the border membrane in $T$. ctenopomae. The posterior blade margin displays a distinct hollow coinciding with the second blade apophysis of the previous denticle in T. ctenopomae. This is less apparent in $T$. microctenopomae. Both these species show the same characteristic when impregnated, that is the oblong distortion of the adhesive disc and its associated structures, which complicated the description and measurements. Measurements were therefore made on both the long and short axis of the adhesive disc, denticle ring and body diameter, in order to compensate for this distortion.

These two new species show resemblance to Tripartiella cichlidarum Basson, Van As et Paperna, 1983 and T. macrosoma Basson et Van As, 1987. The latter is considerably smaller than $T$. ctenopomae and slightly smaller than T. microctenopomae. Tripartiella cichlidarum and T. macrosoma also differ from the present two species in the blade connection angle, details of the blade apophysis and the connection with the following denticle. In $T$. cichlidarum the rays are directed posteriorly. This species was recorded from nilotic cichlid fishes in Israel by Basson et al. (1983), while $T$. macrosoma was found on the gills of Barbus eutaenia, an endemic small cyprinid of southern Africa by Basson and Van As (1987).

\section{REFERENCES}

ASMAT G.S.M., HALDAR D.P. 1998: Trichodina mystusi, a new species of trichodinid ciliophoran from Indian estuarine fish, Mystus gulio (Hamilton). Acta Protozool. 37: 173-177.

BASSON L., VAN AS J.G. 1987: Trichodinid (Ciliophora: Peritricha) gill parasites of freshwater fish in South Africa. Syst. Parasitol. 9: 143-151.

BASSON L., VAN AS J.G. 1993: First record of the European trichodinids (Ciliophora: Peritrichida), Trichodina acuta Lom, 1961 and T. reticulata Hirschmann \& Partsch, 1955 in South Africa. Acta Protozool. 32: 101-105.

BASSON L., VAN AS J.G., PAPERNA I. 1983: Trichodinid ectoparasites of cichlid and cyprinid fishes in South Africa and Israel. Syst. Parasitol. 5: 245-257.

LOM J. 1958: A contribution to the systematics and morphology of endoparasitic trichodinids from amphibians, with a proposal of uniform specific characteristics. J. Protozool. 5: 251-263.

LOM J. 1960: Trichodina reticulata Hirschmann and Partsch, 1955 from crucian carp, and $T$. domerguei f. latispina Dogiel, 1940 from Diaptomus. Vestn. Cesk. Spol. Zool. 24: 246-257.

LOM J., GOLEMANSKY V., GRUPCHEVA G. 1976: Protozoan parasites of carp (Cyprinus carpio): a comparative study of their occurrence in Bulgaria and Czechoslovakia, with the description of Trichodina perforata sp. n. Folia Parasitol. 23: 289-300.

MORAVEC F., VAN AS J.G. 2001: Philometroides africanus sp. n. (Nematoda: Philometridae), a new tissue parasite of the African pike, Hepsetus odoe (Pisces) in Botswana. Folia Parasitol. 48: 127-131.

NILSEN F. 1995: Description of Trichodina hippoglossi $\mathrm{n}$. sp. from farmed Atlantic halibut larvae Hippoglossus hippoglossus. Dis. Aquat. Org. 21: 209-214.
REED C.C., BASSON L., VAN AS L.L. 2002: Myxobolus species (Myxozoa), parasites of fishes in the Okavango River and Delta, Botswana, including descriptions of two new species. Folia Parasitol. 49: 81-88.

SKELTON P.H. 1993: A Comprehensive Guide to the Freshwater Fishes of Southern Africa. Southern Book Publishers, Halfway House, 388 pp.

SKELTON P.H., BRUTON M.N., MERRON G.S., van der WAAL B.C.W. 1985: The fishes of the Okavango Drainage system in Angola, South West Africa and Botswana: taxonomy and distribution. Ichthyological Bulletin of the J.L.B. Smith Institute of Ichthyology, 50, $21 \mathrm{pp}$.

SMIT N.J., DAVIES A.J., VAN AS J.G. 2000: A trypanosome from silver catfish (Schilbe intermedius) in the Okavango Delta, Botswana. Bull. Eur. Assoc. Pathol. 20: 116-119.

STEIN G.A. 1968: Parasitic ciliates (Peritricha, Urceolariidae) of fishes of the Amur Basin. Acta Protozool. 5: 229-244.

SU X., WHITE R.W.G. 1995: Trichodinid parasites (Ciliophora: Peritricha) from the gills of some Australian marine fishes. Syst. Parasitol. 32: 53-59.

VAN AS J.G., BASSON L. 1989: A further contribution to the taxonomy of trichodinid ciliophorans (Ciliophora: Peritrichia) and a review of the taxonomic status of some fish ectoparasites. Syst. Parasitol. 14: 157-179.

VAN AS J.G., BASSON L. 1992: Trichodinid ectoparasites (Ciliophora: Peritrichida) of freshwater fishes of the Zambesi River system, with a reappraisal of host specificity. Syst. Parasitol. 22: 81-109.

VAN AS J.G., VAN AS L.L. 1999: Chonopeltis liversedgei sp. n. (Crustacea: Branchiura), parasite of the western bottlenose Mormyrus lacerda (Mormyridae) from the Okavango Delta, Botswana. Folia Parasitol. 46: 319-325. 
VAN THAN N., MARGARITOV N.M. 1986: Status and morphometric data of some species from the family Urceo-lariidae, parasitising on the breeding stock of phyto-phagous fish in Bulgaria. Acta Zool. Bulg. 30: 2535.

XU K., SONG W., WARREN A. 1999a: Trichodinid ectoparasites (Ciliophora: Peritrichida) from the gills of

Received 23 May 2001 cultured marine fishes in China, with the description of Trichodina lomi. Syst. Parasitol. 42: 219-227.

XU K., SONG W., WARREN A. 1999b: Trichodinid ectoparasites (Ciliophora: Peritrichida) from the gills of mariculture molluses in China, with the descriptions of four new species of Trichodina Ehrenberg, 1838. Syst. Parasitol. 42: 229-237.

Accepted 8 February 2002

\section{Erratum}

Køie M.: Spirorbid and serpulid polychaetes are candidates as invertebrate hosts for Myxozoa. Folia Parasitol. 49: 160-162, 2002.

In the above article, the first word of the title appeared wrong. The correct spelling is given above. The author and the editor regret the error. 